\title{
ラット眼窩下神経挫滅後の触覚性誘発電位の回復過程の研究
}

\author{
白木 豊
}

\section{Study on the recovery processes of the tactile evoked potential after infraorbital nerve crushing in rats}

\author{
Yutaka SHIRAKI
}

\begin{abstract}
The changes in latency and amplitude of the cranial evoked potentials(EP) generated by mechanically stimulating the whiskers were measured in adult rats, in which the unilateral infraorbital nerve innervating the whiskers was crushed.

1. In normal rats with intact infraorbital nerves, disphasic EPs were recorded subcutaneously from the contra and ipsilateral hemisphere. Latency of the contralateral waves was always shorter than that of the ipsilateral ones.

2. Immediately after crushing the unilateral infraorbital nerve, latency of the contralateral EPs evoked by stimulating the crushed side whiskers was prolonged with a significant correlation between the positive and negative component of the EPs. Latency of the EPs simulataneously recorded from the ipsilateral side showed no significant changes. As a result, in some cases latency of the ipsilateral EPs became shorter than that of the contralateral ones. Most of these changes were restored within 3 weeks.
\end{abstract}

3. The contralateral positive and negative EPs evoked by stimulating the crushed side whiskers showed immediate amplitude reduction. Positive EPs recorded from the hemisphere ipsilateral to the stimulation was consistently reduced in amplitude, while in the negative component, increases and decreases in amplitude were found to occur at roughly the same frequency. In the ipsilateral evoked positive component, the amount of amplitude reduction tended to show a positive correlation with the length of time needed to recover control value.

4. The ratio of the latency after crushed side stimulation to that after intact side stimulation ( $\mathrm{C} / \mathrm{I}$ ratio) was increased significantly for one week after the nerve crush. The ratio of amplitude of the negative component to the positive component of individual EPs ( $\mathrm{N} / \mathrm{P}$ ratio) was found to be smaller for one week in the EPs evoked on the contralaterral hemisphere by stimulating the crushed side whiskers. The $\mathrm{N} / \mathrm{P}$ ratio of the EPs on the ipsilateral hemisphere by stimulating the crushed side whiskers was increased at the 1 st week after the crushing. These changes returned to normal at the 2 nd week.

These results indicated that reliable parameters to predict recovery time course of the tactile function after infraorbital nerve crushing would be (1) the $\mathrm{N} / \mathrm{P}$ ratio of amplitude of the EPs evoked simultaneously on both sides of the head following stimulation of the crushed side whiskers, and (2) the $\mathrm{C} / \mathrm{I}$ ratio of latency of the EPs evoked through the crossed pathway on the contralateral hemisphere by stimulating the crushed or intact side whiskers.

Key words: nerve crush, infraorbital nerve, evoked potential

愛知学院大学䀳学部第 2 口腔外科学教室

(主任：河合 幹教授)

The Second Department of Oral and Maxillofacial
Surgery, School of Dentistry, Aichi-Gakuin University (Chief: Prof. Tsuyoshi Kawai)

受付日：昭和 62 年 5 月 22 日 


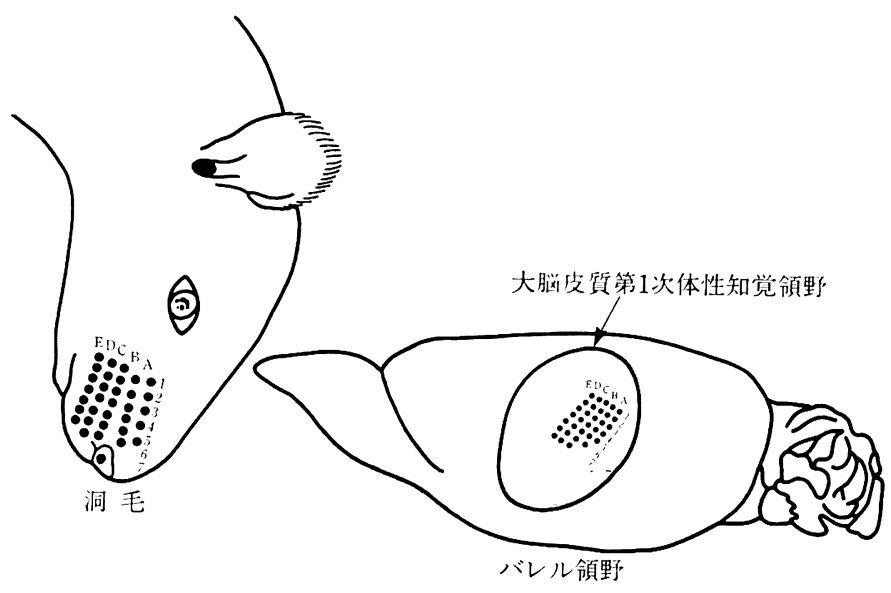

図1バレル領野

緒

\section{言}

外科手術時に誤って，またまれには不可避的に知覚神 経に損傷を与えることがある。特に，指尖と同程度の触 覚弁別能を有する口唇, 舌などを含む三叉神経領域にお ける知覚麻㿁の影響は，患者にとりきわめて重大であ る. しかし, 知覚麻瘦, 知覚低下の程度を定量化・客観 化し,さらに回復の予後を推察することは, 知覚が主観 的なものである以上非常に困難である.

近年, 知覚の強弱の程度をヒトにおいて大脳誘発電位 (evoked potential：以下EP と略) を利用して定量化し ようとする研究がなされている，Franzén ら ${ }^{1)}$ は，指尖 に種々の強さの触刺激を与光, 刺激した指と反対側頭部 での EP を検討し, 刺激強度と EP の振幅との間に相 関性を見いだしている。また，Johnson ら²は同様な研 究で $\mathrm{EP}$ のうち, $120 \mathrm{msec}$ 以後の遅い成分の振幅が刺 激の強さと相関を有するとしている。一方, Yamauchi ら ${ }^{3)}$ は刺激の種類汇注目し, 機械的刺激と電気的刺激を 行い, 前者が EP の遅い成分では後者に比べて相対的に 短い潜時を有することを示した。また，村山(4) は一側指 の電気刺激の強さと対側の頭皮上初期 EP (潜時約 30 $\mathrm{msec}$ ) の振幅間に相関を見いだすのと同時に, 刺激強度 と主観的感覚量とは達い成分に相関があり，EPの早期 成分は体性感覚入力の処理過程にそれぞれ関与すると推 察している。このように, 知覚を EP で定量化・客観化 しょうといら試みはなされてきたが，その実用価值はい まだ確立しているとはいい難い。

一方，末梢神経の損傷・回復過程を電気生理学的に追 及したものは数多く認められるら 10)。しかし，これらは 末梢神経そのものに抢ける活動電位の変化をみたもので

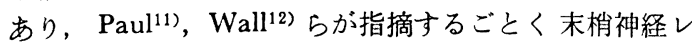

ベルでの再生は必ずしも知覚における最終投射野である 大脳皮質知覚領野における機能回復とは結びつかない，

本研究は, 臨床応用が可能な方法で, 感覚量と EP が 前述のごとくある程度の平行関係を有することを利用 し, 未梢神経損傷後の感覚機能回復を大脳皮質レベルで 客観的に定量化しょ5と試みた。

1970年 Woolsey ${ }^{13}$ ) は洞毛（sinus hair）から大脳皮質 知覚領野に強力な投射関係があり，その投射野をその特 異な形態からバレル（樽）領野と命名した。バレルは， 大脳皮質第 $\mathbb{V}$ 層に位置する直径 $100 \sim 400 \mu \mathrm{m}$ の多細胞 構築体であり, 神経細胞は樽の壁に相当する部分に密集 し, 禋の内部に相当する部分には神経細胞はほとんど存 在していない.Welker ${ }^{14)}$ は, 洞毛に対する機械的刺激 とそれにより惹起される誘発電位の研究で, 各洞毛と各 ハレルに 1 対 1 の対応があり, 洞毛の背側から腹側への 関係 $(\mathrm{A} \sim \mathrm{E}$ 列) が第一次知覚領野 $(\mathrm{SmI})$ で尾側から 吻側へと，また洞毛の尾側から吻側への関係（1本〜数 本）が同領野で背側から腹側へと整然と配列されている ことを示した（図1），さらに同領野で頭頸部からの投 射が $2 / 3$ の面積を占める内で洞毛からの投射がその $30 \%$ を占めるとし，洞毛からバレル領野への強力な投射関倸 を示した，その後， Simons ${ }^{15)}$ は，1つのバレル内の神 経細胞は他の洞毛からの入力にも反応することもある が，ほとんどの場合洞毛とバレルの関係は 1 対 1 である と記載している。このように1本の洞毛と 1 個のバレル とは非常に密接な対応関係があるので, 本研究では洞毛 求心性経路である眼窩下神経を挫減する前後に，洞毛を 機械的に刺激した際生ずる頭皮下誘発電位の变化と，そ の回復過程を経時的に観察した. 


\section{実験材料および研究方法}

\section{1. 実験材料}

ウィスター系雄ラット（200～250 g）を使用した。麻 醉は，毎回硫酸アトロピン（硫アト®） $0.01 \mathrm{mg} / \mathrm{kg}$ を筋 注 30 分後に，ペントバルビタール(Nembutal@) を 50 $\mathrm{mg} / \mathrm{kg}$ 腹腔内に注入した。麻酔後，成茂社製脳定位固 定装置（ST-7）に固定した。この際，洞毛のC列がほぼ 水平になるように調節し，体温を一定に保つため保温装 置を使用した。

\section{2. 刺激方法}

一側の全洞毛がC列の 3 番目を中心に集中するように テープで固定した．固定された両側の洞毛に電磁オシロ グラフのペンモーターを利用した刺激子で，持続時間 $0.1 \mathrm{msec}$ の矩形波により一定の機械的刺激を加えた。 なお，この際，洞毛束の中心が背側方向へ $5^{\circ}$ 偏位を起 こすよう，刺激子の固定位置を調節した（図 2 ）。

\section{3. 誘発電位の記録}

電極はエナメルにより被覆, 絶縁した歯科用 18-8 ス テンレス製 K-File (Kerr 社製, 尖端 $250 \mu \mathrm{m}$ ) の尖端 をヤスリにより露出させ単極電極として使用した。電極 は微動装置を用いて，外耳孔を結んだ線が正中線と交わ る点を中心として前および側方を $1 \mathrm{~mm}$ きざで移動さ せた，EP の記録に際しては，電極を毎回頭皮を貫いて 頭蓋骨と接触させた。不関電極は，銀線を頭部後方の皮 下に刺入した。採取された EP は増幅器を介してオシ口 スコープ (TEKTRONIX, R 5103) で観察しながら積 算記憶装置（日本光電, ATAC-350）で50回加算した。 加算平均された EP の波形を X-Y レコーダ（渡辺測
器，W-X 4411) に描記させた。 また同時に，すべての EP を磁気テープに保存 (SONY, DR-FE 3000) した.

\section{4. 刺激および EP 採取条件}

（1）麻酔深度：麻酔深度による影響をできるだけ一定 にするために，4 4 匹のラットで腹深内注入後60分-180分 まで15分間隔で，刺激と対側の EP の陽性波之陰性波の 振幅を計測した。陽性波は麻酔深度による影響が陰性波 と比べて少なく，平均変動範囲は土 $22.6 \%$ であった。陰 性波は, 投与後, 時間経過とともに振幅の增大が認めら れた（図3）。しかし，投与後 120 分～150分の間は振幅 変動が $14.7 \%$ 以内であったので，この期間の EP を測

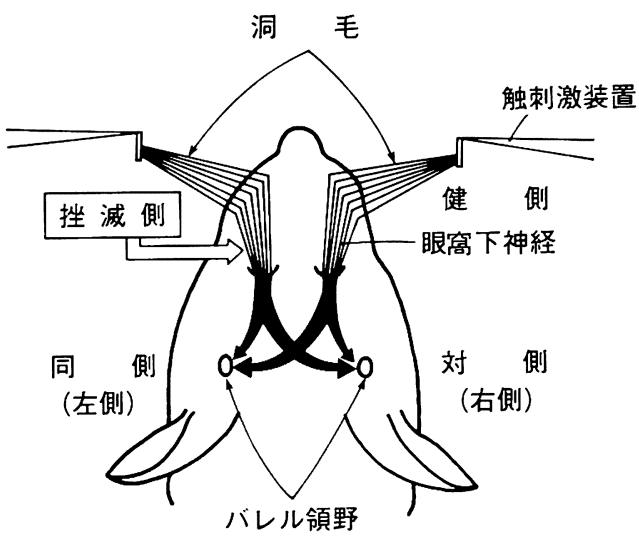

図 2 実験方法

両側洞毛に機械的刺激を加え左側眼窩下神経を 挫滅し, EP 変動を記録した。頭蓋部の矢印は, 交叉性诂よび非交叉性上行経路を示す。

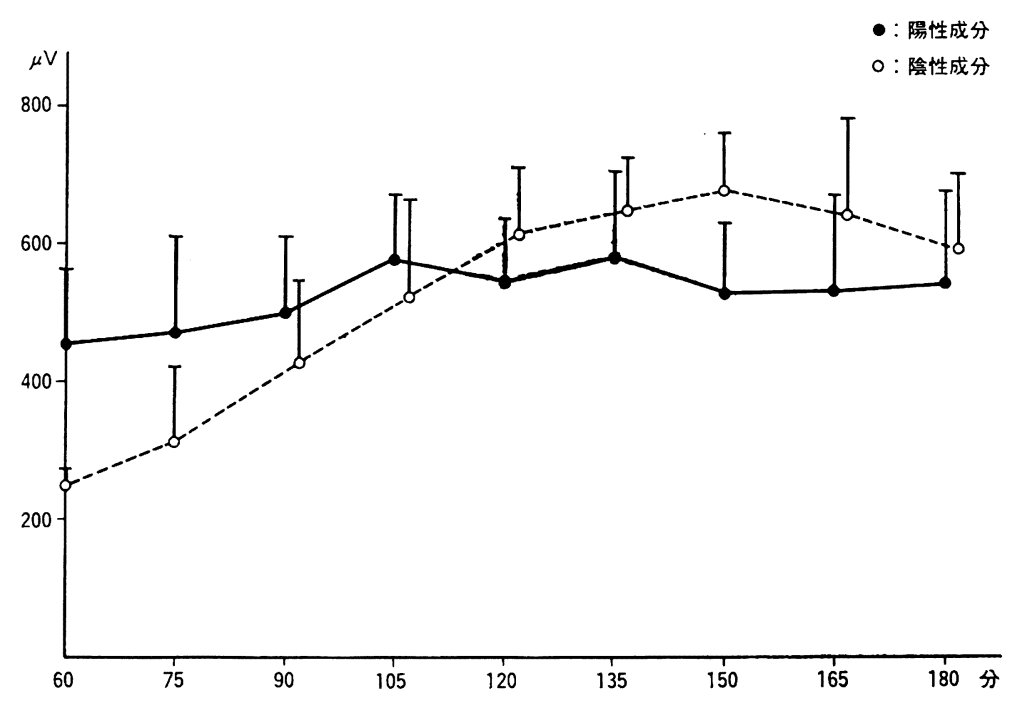

図 3 麻酔深度と振幅の関係 

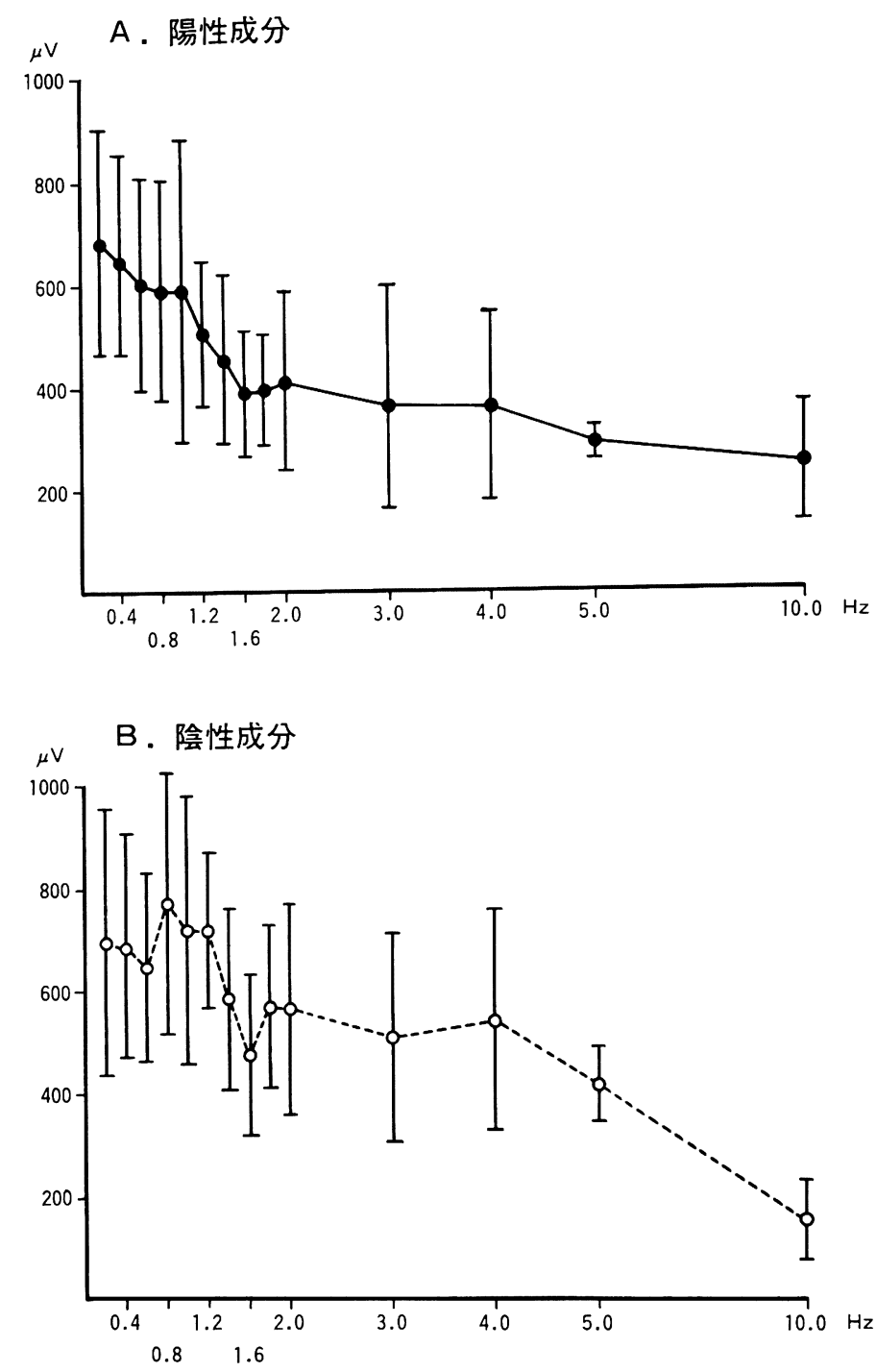

図 4 刺激頻度と振幅の関係

定の対象とした。

(2) 刺激頻度 : 腹腔内麻醉 120 分後に $0.2 \mathrm{~Hz} \sim 10 \mathrm{~Hz}$ の刺激を加え, 対側 EP の振幅変化を調べた $(n=4)$. 陽性波では $1.0 \mathrm{~Hz}$ を越えると，陰性波では $1.2 \mathrm{~Hz}$ を 越えると振幅の減弱が始まった（図４），乙れ帄兄，頻 回刺激の影響がほとんど認められず，しかも比較的短時 間内に電位採取を完了し得る $0.4 \mathrm{~Hz}$ に刺激頻度を固定 した。

（3）電極の位置：上述（1），(2）の条件下で最大の EP を採取し得る部位を探した $(\mathrm{n}=4)$. 刺激と対側 で，陽陰性波ともに最大の振幅を示すことが最も多い位 置は, 体重 $200 \mathrm{~g}$ のラットでは, 両側外耳孔を結んだ線
と正中線が交叉する点より前方へ $3 \mathrm{~mm}$ ，側方へ $9 \mathrm{~mm}$ の位置であった。刺激と同側頭部にも対称的に電極を設 睍した。これらの位置は, ほぼ頭頂一側頭縫合部に合致 した．ラットのその後の成長にあわせて，毎回，上記の 電極の位置を中心として振幅が最大となる位置に電極を 移動させた。

\section{5. 実験群}

12 匹のラットの左側煩骨弓部に皮膚切開を加え, 手術用顕微鏡下で，神経に対してできるだけ侵襲を加え ないよらに注意しながら，鋭的に左側眼窩下神経を分離 した，神経分離後，オシロスコープ上で $\mathrm{EP} に$ 変化がな いことを確認した後，ピンセットで分岐しているすべて 


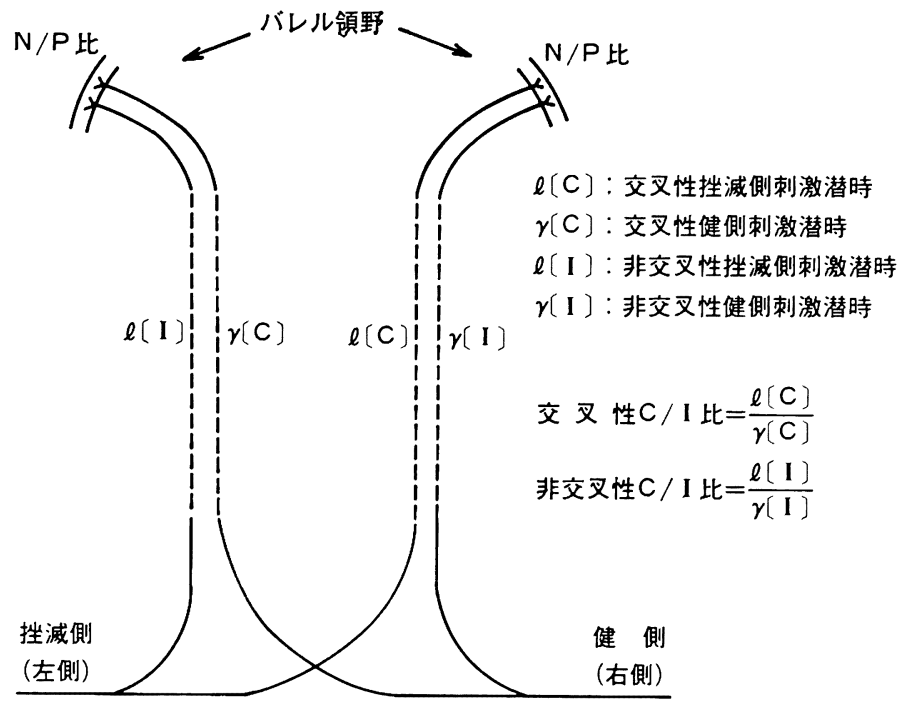

図 5 交叉性. 非交叉性 $\mathrm{C} / \mathrm{I}$ 比と両側頭部 $\mathrm{N} / \mathrm{P}$ 比

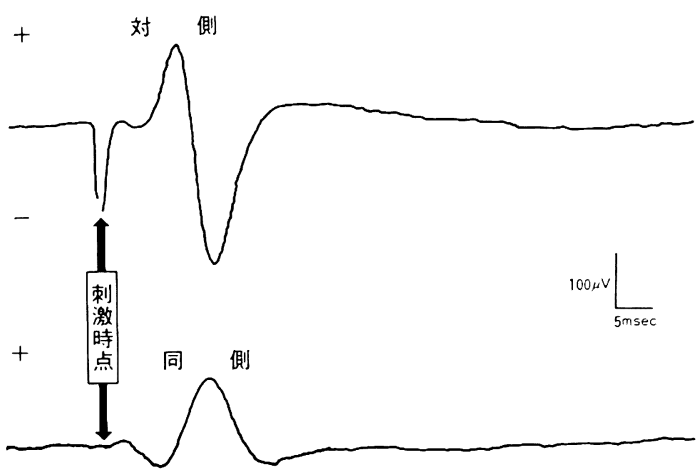

図,6 誘 発電 位

の眼窩下神経の枝を幅 $1 \mathrm{~mm}$ の範囲で， $180 \mathrm{~g} \sim 200 \mathrm{~g}$ の 圧で10秒間圧迫挫減した。皮店創部は，ナイロン采で維 合し，感染予防のため抗生物質を 3 日間投与したが， 全例とも創の治瘉状態は良好であった。挫減直前および 直後に, 挫隇側 (左側) と健側 (右側) 洞毛刺激による 両側頭部の EP を記録した。その後は，1週ごとに EP の変化を観察した。

\section{6. 対照群}

眼裔下神経に侵襲が加えられていない8 匹のラット で, 対側および同側の EP の潜時と振幅の経過を 1 週ご とに記録した。麻酔法, 洞毛刺激方法, EP の記録方法 は，すべて実験群と同様とした。

\section{7. 分析方法}

実験群でのラットでは，おのおののデーター.を，挫隇

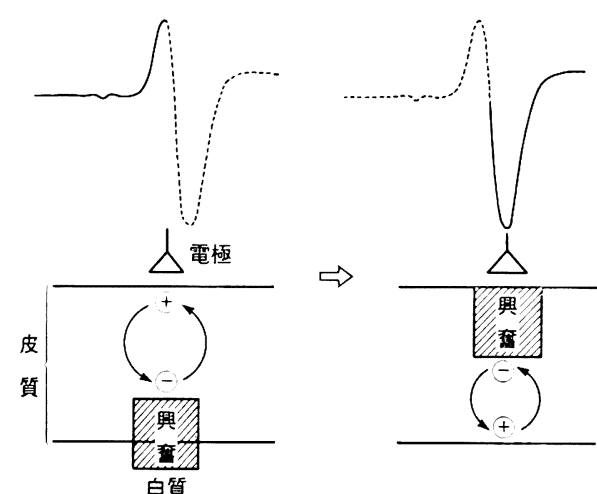

図 7 誘発電位の成因

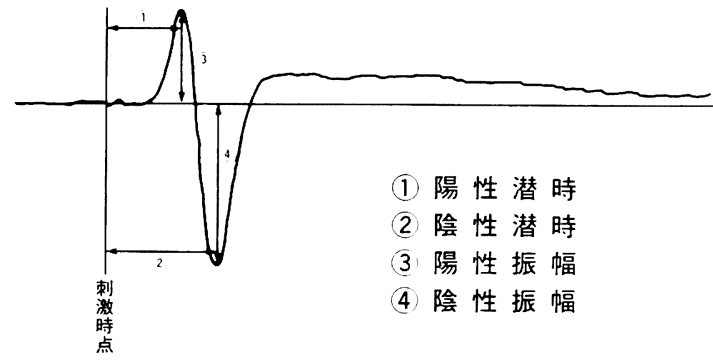

図 8 計 測 基 準

前の振幅および潜時を基準とする相対值として表示し た，回復の基準は対照群との相対値で表示した。すなわ ち，潜時に関しては陽性および陰性波の頂点潜時が，対 

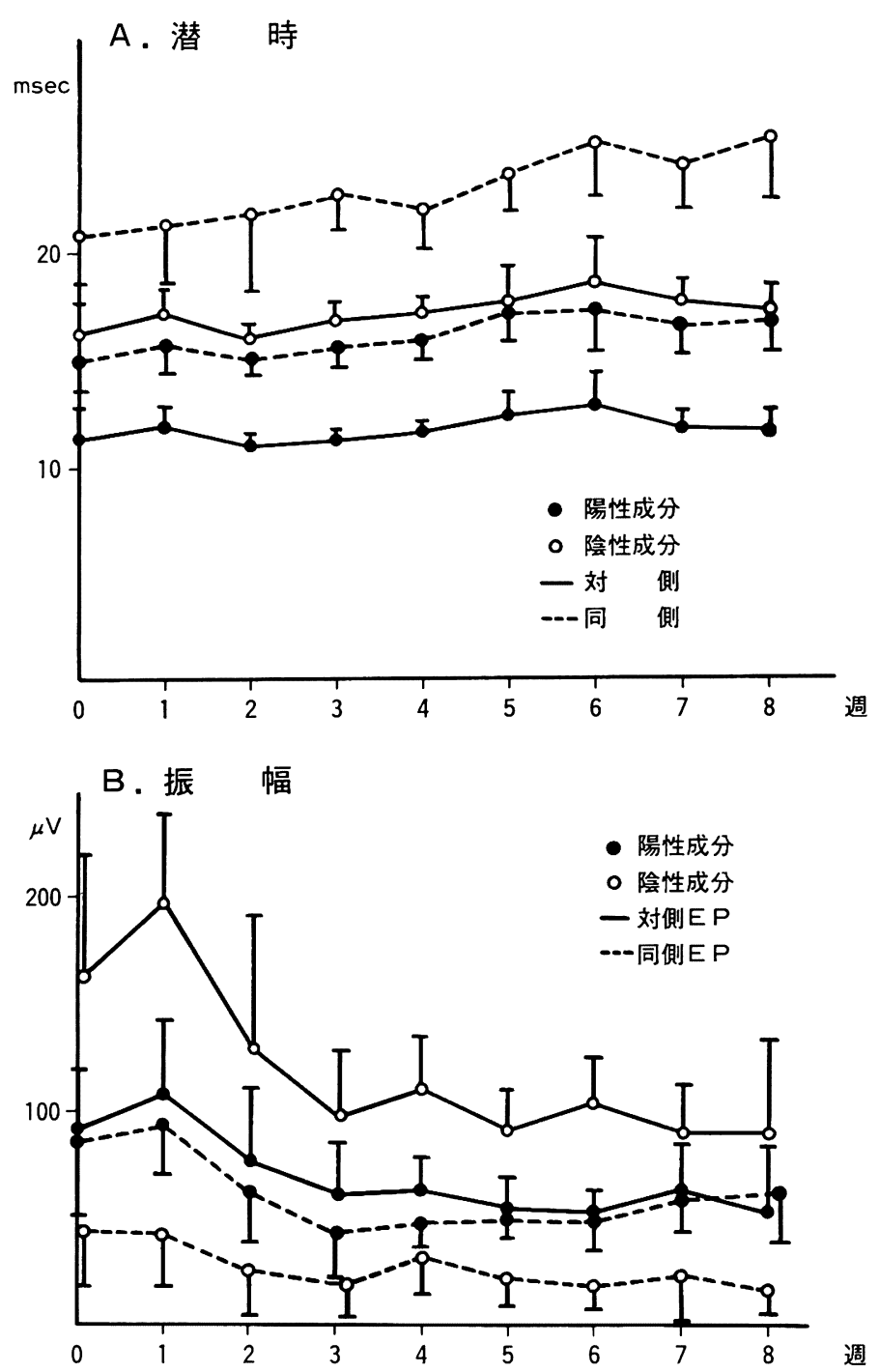

図 9 対 照 群

照群の平均値に達した時点で回復と見なした。一方，振 幅に関してはより敞格な基準を採用し，おのおのの振幅 が対照群の平均值を上回った時点で回復と見なした。こ の理由は, 対照群の振幅の変動が潜時の変動よりもはる かに大きかったからである。 また，交叉性上行経路と非 交叉性上行経路との間の差異を調べるために，潜時につ いては，挫減側刺激によって片側頭部で得られる陽性お よび陰性波の各潜時を, 健側のそれらで除した值（挫減 側刺激潜時/健側刺激潜時, 以下 $\mathrm{C} / \mathrm{I}$ 比とする）の平均 および偏差を求めた。ささらに, 眼窩下神経挫減に基つく 入力変化に起因する皮質下部および皮質表層での興奮処 理の様式の変化を調べるために, 挫隇側および健側刺激
による片側 EP の陰性成分と陽性成分の比（以下， N/P 比とする) の平均值と偏差を求めた（図 5 ). 同様の計 測処理を他側の反応についても行った.

結果

\section{1. 対照群の成績}

（1）対照群の EP の波形と計測基準

刺激側から見て対側, 同側ともに陽性成分之陰性成分 からなる 2 相性の EP が採取された（図 6). 全振幅は, 対側で $257 \pm 78 \mu \mathrm{V}$, 初期陽性波の頂点潜時が $11.3 \pm 1.4$ $\mathrm{m} \mathrm{sec}$ であった．対側の振幅は同側のそれの約 2 倍の大 

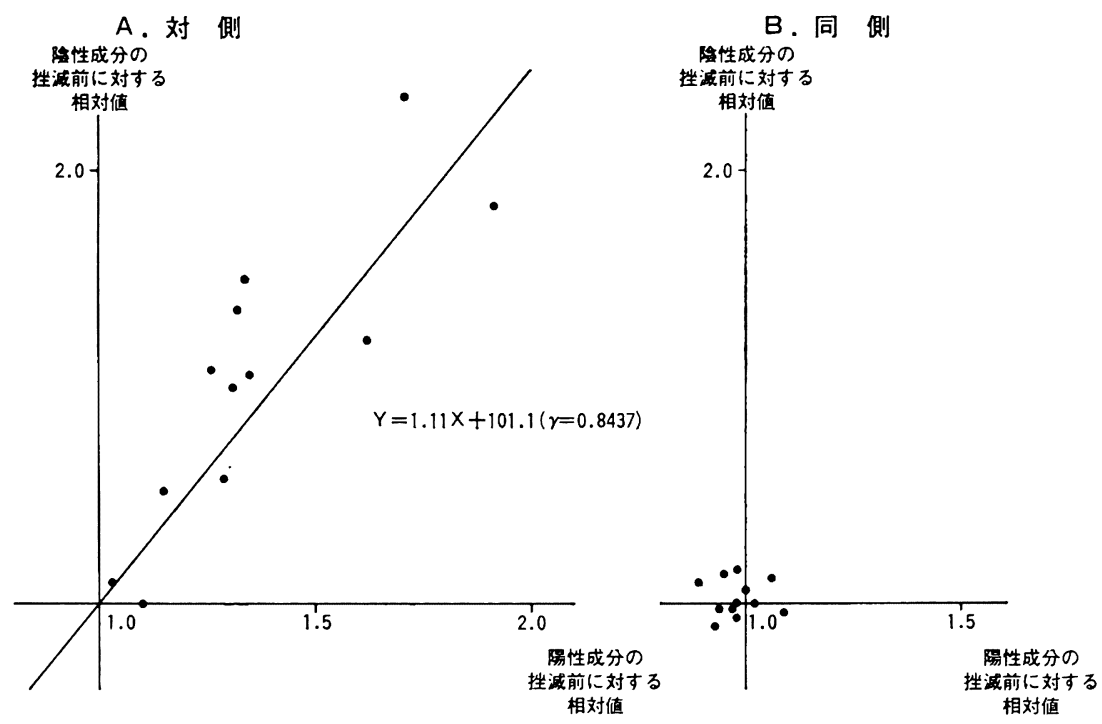

図 10 挫滅直後の潜時変化

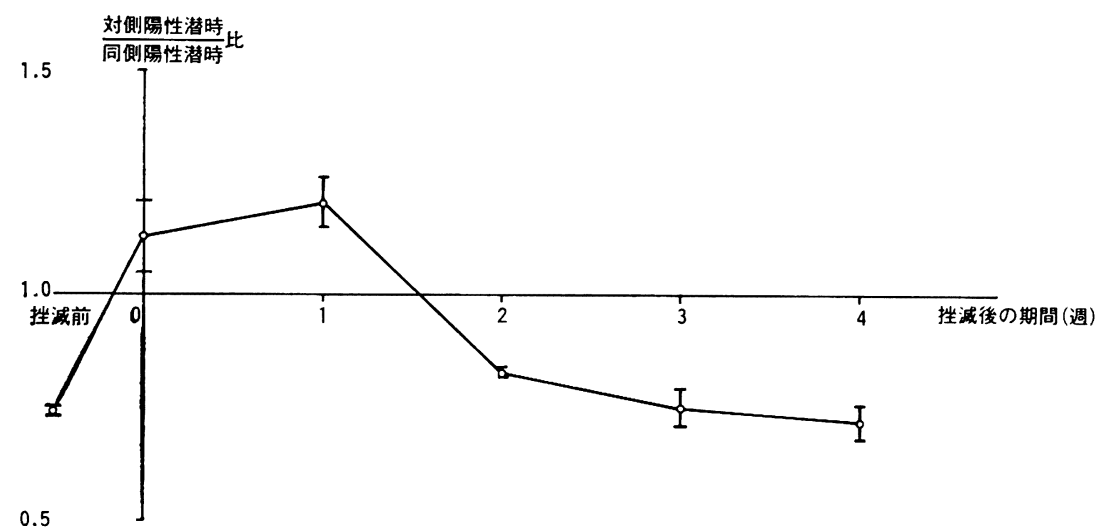

図 11 挫隇後の対㑡拉よび同㑡陽性 EP 潜時の相対值の逆転

きさを有していた，また，対側陽性成分の振幅は陰性成 分のそれに比べて常に小さく，同側ではその関係は逆で あった。 また，潜時は陽性波，陰性波ともに対側が常に 短く，同側ではどちらも約 $4 \mathrm{~m} \mathrm{sec}$ 長かった。

陽性波, 陰性波のそれぞれの成因は，陽性波が皮質下 部，すなわち白質から皮質深層における興藟を表し，陰 性波は皮質内部で表層に抁がる興奮を示すとされている （図 7). それゆえ，成因の異なる 2 つ波のピークまで の潜時と振幅を計測してそれぞれ別個に分析を試みた (図 8).

（2）対照群における潜時, 振幅の経過

潜時は，8週目まで週秢とともに延長する傾向にある ものの変化は少なく安定していた。一方, 振幅は両側の
陽陰雨波とも次第に減弱し，8週目には平均值で串騟初 日の約70\%近くまで低下した（図 9).

\section{2. 実験群の成績}

（1）挫隇後の潜時変化

奏験群の潜時変化を挫減直後から，4〜8週目まで記 録した。

(1) 挫隇直後の変化: 挫隇側 (左側) 洞毛刺激により 対側 (右側) の EP は陽性・陰性成分ともに潜時の延長 を認めた（図 10A）。図に示されたよらに両波の延長度 にはかなり強い正の相関（相関係数 $\mathrm{r}=0.8437, \quad \mathrm{p}<$ 0.01) が認められた。これに対し，左側の EP では陽 性・陰性成分ともに変化が極めて少なく（図10B）, ᄂ かもわずかながら短縮を示すものが陽性波では12例中 8 


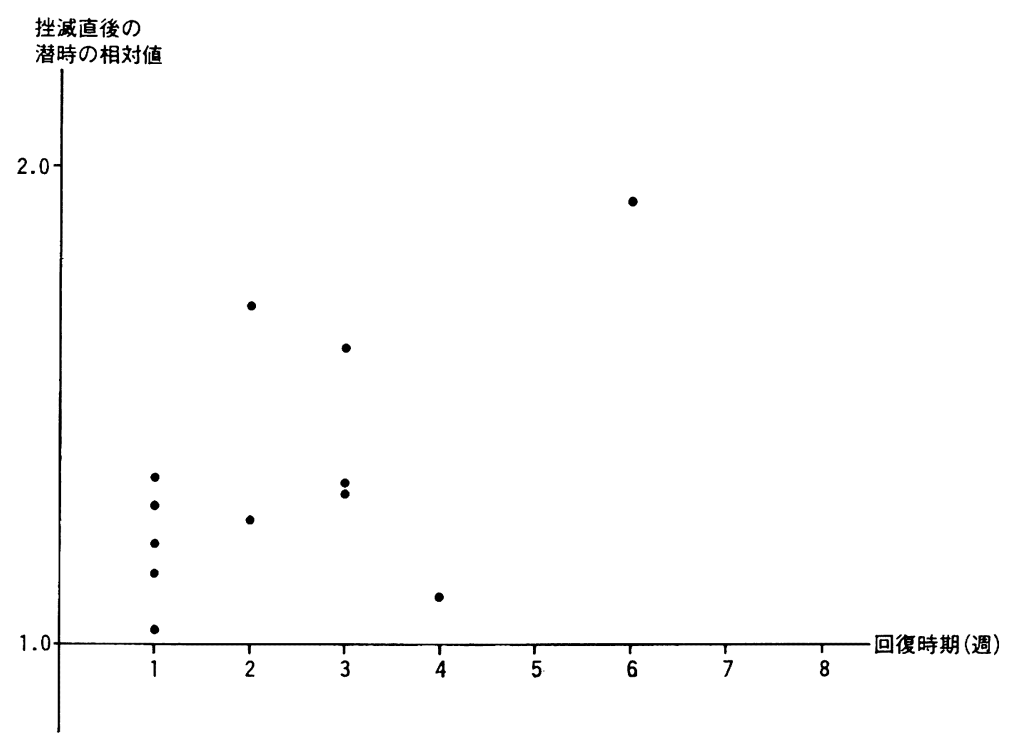

図 12 挫減直後の対側陽性波 EP の潜時延長度と回復時期

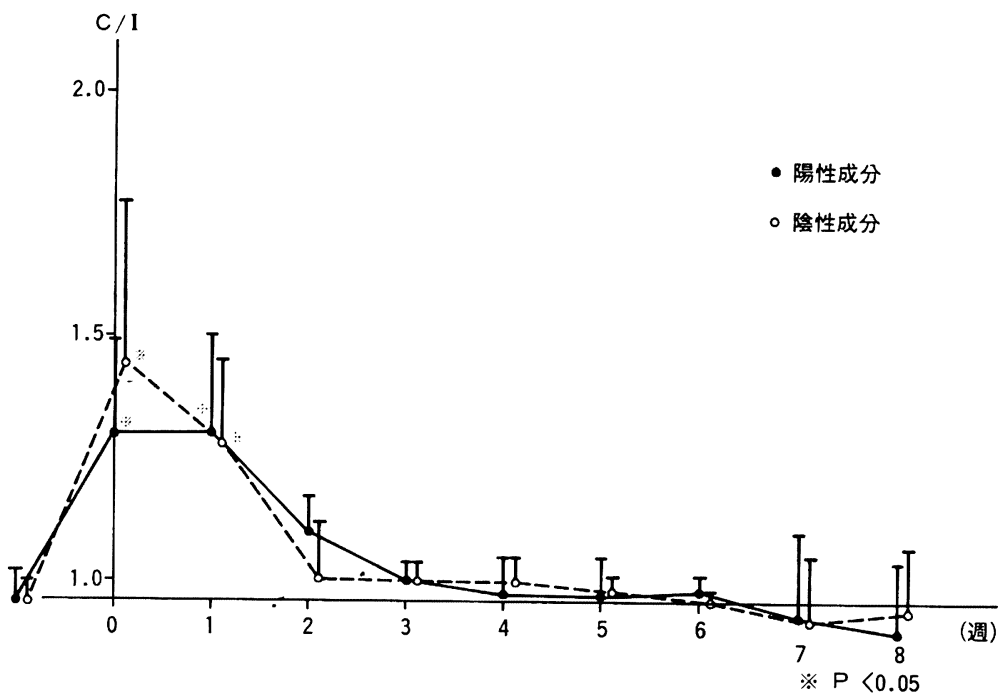

図 13 交叉性上行路 $\mathrm{C} / \mathrm{I}$ 比の推移

例あった。同時に测定された右側陽性波の潜時が延長し ていた結果, 左側潜時に対する右側潜時の相対関係は, これらの 8 例では挫隇前とは逆となった（図 11）.

(2) 潜時変化と回復期間 : 左側 (挫減側) 洞毛刺激によ り右側で得られた EP の陽性波の潜時は, 対照群から得 られた基準経過曲線に当てはめた場合，3週目までに回 復したものが大部分であった（図 12）。なお，潜時延長 度と回復期間との間にはきわめて低い正の相関を認める のみであった（ $r=0.5758, p<0.05)$. 陰性波ではそ
のような相関関係は全く認められなかったが， 3 週目ま でに回復したものがほとんどであった。挫隇直後に左側 陽性波の EP 潜時が右側のそれに比べて短縮した群で は，1週後までその逆転現象が持続し，2週目には挫隇 前の関係を回復した（図 11）。

健側刺激では, 両側頭部の陽・陰性波ともに潜時変化 はほとんど羿められなかった。

交叉性経路（挫隇した左側眼窩下神経から右側頭部へ 向から経路と, 健常な右側から左側頭部へ向から経路） 


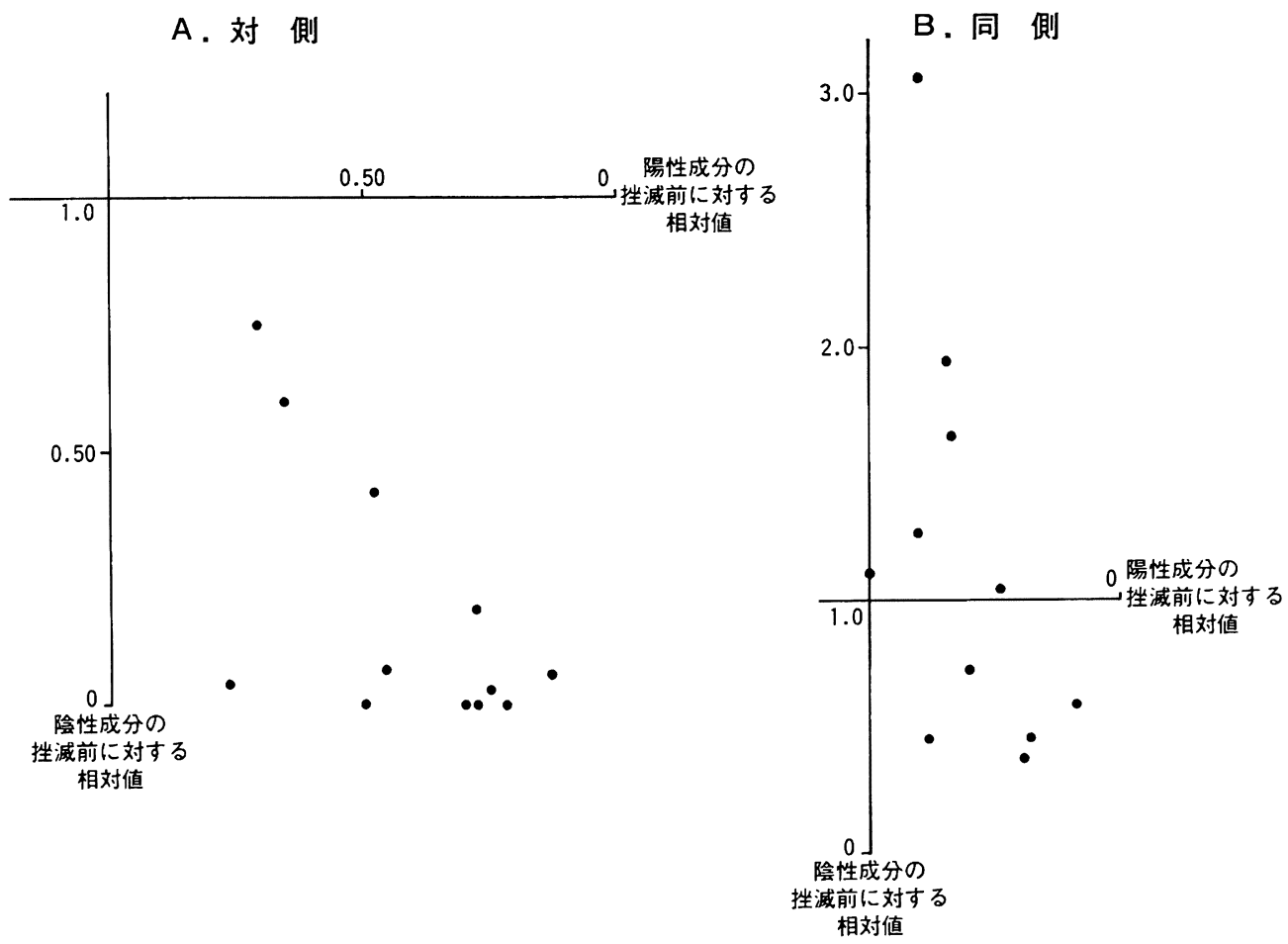

図 14 挫隇直後の振幅変化

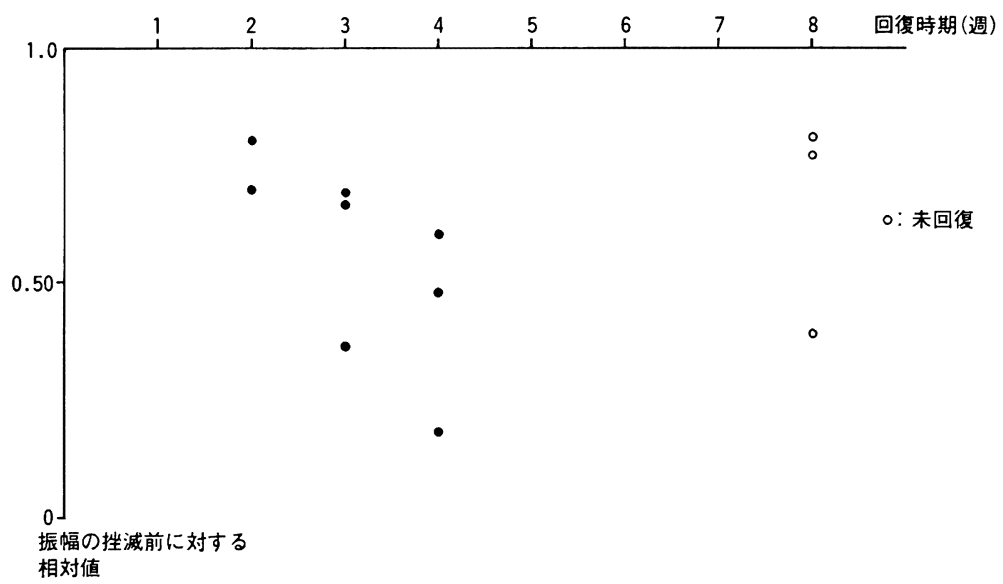

図 15 挫減側刺激による同側陽性波 EP の挫隇直後の振幅低下度と回復時期

の陽および陰性波の潜時を比較した。C/I 比を唡討した ところ, 挫減直後から 1 週目にかけて Mann=Whitney のU検定で $5 \%$ の危険率で有意な上昇を認めた（図 13). この変化は 2 週目で有意差が認められなくなった。非交 叉性経路に関しては，両成分とも有意な変化を認めなか った。

(2) 挫隇後の振幅変化
(1) 挫隇直後の変化: 挫隇側 (左側) 洞毛刺激で右側の 陽・陰性波はすべての例において振幅の低下を認めた （図 14 A ）。振幅低下の程度は種々であったが，陰性波 の減弱度が陽性波の減弱度に比べてより強かった。左側 頭部においては，挫隇側洞毛刺激の陽性波は，右側と同 様にすべての例において軽度にまたは著明に低下した。 しかし，陰性波では低下するものと增大寸るものとが㴗 


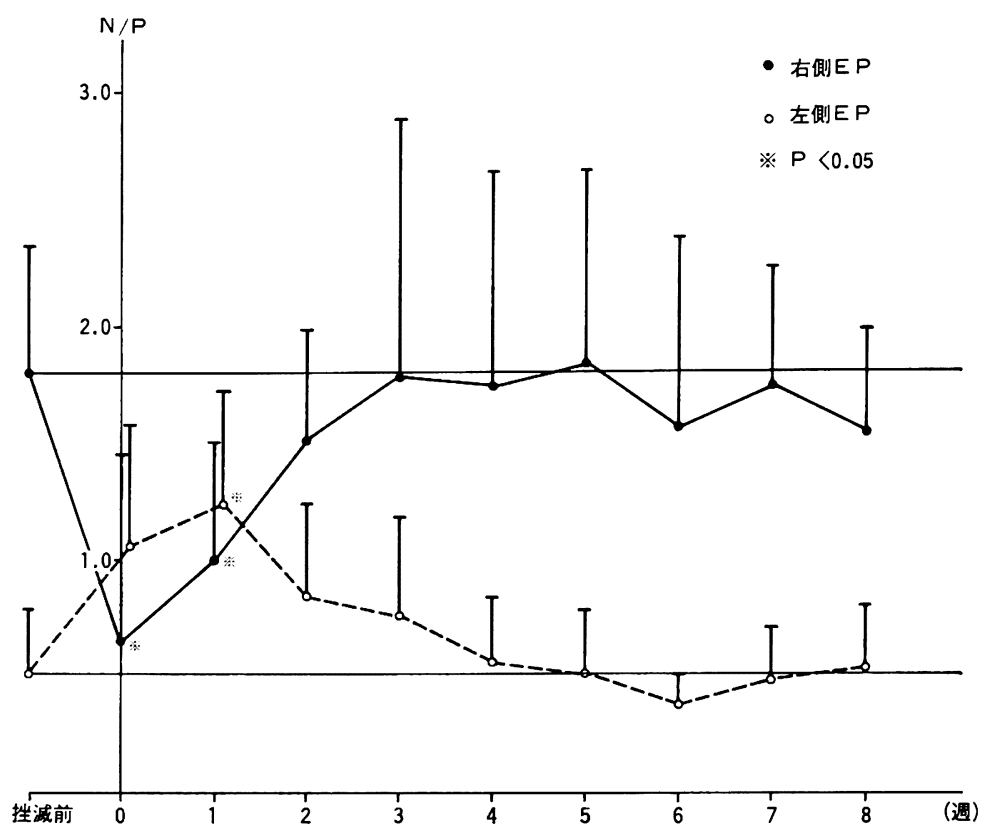

図 16 挫減側洞毛刺激による両側頭部 $\mathrm{N} / \mathrm{P}$ 比の推移

ぼ同数であった（図 14B）.

(2) 振幅变化と回復期間：挫隇側洞毛刺激に上る右側 $\mathrm{EP}$ 波の変化と回復時期との間には明らかな相関は認め られなかったが, 左側 EP の陽性成分の振幅低下度と回 復期間との間に正の相関傾向を認めた（図 15）。その他 の成分すなわち左側陰性波, 右側陽・陰性波は, 挫減直 後の振幅低下の程度とは無関係に大部分が 3 週目までに 回復した。しかし，少数ではあるが 8 週目においても対 照群の水準に達しない例も認められた。挫隇直後に，挫 減側刺激により惹起された右側 (対側) EP の N/P 比 が，低下した。これは，Mann=Whitney のU検定で 5 \%の危険率で有意であった。この有意差は 1 週目まで持 続し，2 週目以降は有意差が認められなくなった（図 16)。左側 EP では挫隇直後に, 挫減側洞毛刺激による $\mathrm{N} / \mathrm{P}$ 比は, 右側とは逆に上昇傾向が見られ 1 週目では $5 \%$ の危険率で上昇汇有意差を認めた。この変化も右側 と同じく2 週目で回復した，一方，健側洞毛刺激では， 交叉性および非交叉性 $\mathrm{N} / \mathrm{P}$ 比に有意差を認めなかった。

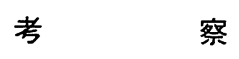

\section{EP の波形と感覚上行路}

対照ラットの洞毛刺激により対側の頭部で得られた $\mathrm{EP}$ は, 2 相性で振幅が約 $250 \mu \mathrm{V}$, 陽性潜時が約 $11 \mathrm{~m}$ sec であった. Waite ら ${ }^{16)}$ がガラス微小電極を使用して 平均値で約 $600 \mu \mathrm{V}$ の振幅を得ているが，偏差も著しく
大きい. 本研究結果との差異は, 刺激方法, 電極などの 採取条件の違いによると考元られる，同側の EP は対側 の約 $1 / 2$ の振幅であった，潜時は，同側の陽性成分，陰 性成分ともに対側に比べて約 $4 \mathrm{~m} \mathrm{sec}$ 長かった。この潜 時の差異は Pidoux ら ${ }^{17)}$ の報告とほぼ合致している.

洞毛から対側バレル領野への強力な投射があること

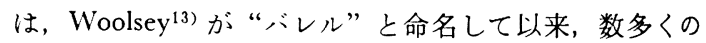

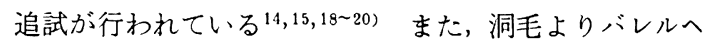
至る各中継核に関寸る研究も多い，Zucker ${ }^{21)}$ は三叉神 経節で洞毛刺激の方向と速さに対する反応性と適応度な どからニューロンが 5 つのカテゴリーに分類されるとし た. 洞毛から三叉神経核への投射は, horse radish peroxidase (以下, HRP と略) の順向性の軸索輸送の検索 の結果, 三叉神経主知覚核, 脊㭪道路核の全域に到ること が明らかにされている22).対側視床への投射に関しては, Waite ${ }^{23)}$ が腹側基底核全体の $1 / 3 \sim 1 / 2$ の部位で洞毛の機 械的刺激に対する応答が得られたとし，Fukusima ${ }^{24)}$ は 三叉神経核主知覚核, 春蹃路核中間亜核, 尾側亜核から 対側視床腹側基底核へ HRP が輸送されることを証明す るとともに，視床外腹側核とバレルの存在する大脳皮質 IV層との経路についても言及している.

同側洞毛からの経路に関しては, Pidoux $5^{17)}$ の研究 がある.これは(1)刺激洞毛と対側のバレル領野を破壊す ると同側 EP が消失する, (2)対側バレルの冷却により同 側 EP が消失するが，その後の加温により再度同側 EP の出現を認める，(3)脳梁を切断すると同側 EP が消失す 
る，(4)対側に比べ同側 EP は 4〜5 $\mathrm{msec}$ の潜時の達延 を認める,などの理由から洞毛からの興奮は, 対側バレ ルに達した後に交連線維を経て同側バレルに達すると結 論づけている. しかし，この結果は 1 本の洞毛刺激によ るものであり，知覚に関しては同側の経路もあることが 一般的である。.Fukusima ${ }^{24)}$ も三叉神経核主知覚核から 同側視床腹側基底核への経路を見い出している．本研 究では, 挫隇側と同側の陽性潜時が対側のそれより短縮 することがあったので，同側経路も機能的に有意義であ ると考兄られる。すなわち，本研究では全洞毛を刺激し たので, 上行性入力が加重し, 正常な場合には非常に弱 い伝達経路としての役割しか果たし得ない三叉神経核か ら同側視床を経て同側バレル領野に達する経路が，眼窩 下神経挫隇後においては有効な経路として機能すること が示唆される.

\section{EP に影響を与える諸要因}

眼窩下神経を可及的に同一条件で挫減したところ，対 側 $\mathrm{EP}$ は種々の程度で陽および陰性成分の振幅低下を認 めたが，各個体間の差異が著しかった。この理由の $1 つ$ は, 眼䈑下神経の神経線維のうち, 洞毛支配の線維で挫 隇を受けたものの数とその程度が一様ではなかったこと であろう．直径の大きい線維は圧迫により障害を受けや すい ${ }^{25,26)}$. 洞毛支配の神経はほとんど直径の大きな有䯣 線維であるので27), 挫減させるのは比較的容易ではあろ 5. しかし，一定圧により挫減した場合でも，個々の線 維の挫隇の程度はさまざまとならざるを得ない，挫隇直 後の EP の振幅低下の主たる原因は, 眼窩下神経を通っ て上行する活動電位の総数の減少である. 挫減局所の 1 本の神経線維上で活動電位の伝播が阻止されるために は，挫隇程度が一定以上であれば十分で，その線維にそ れ以上の強い挫減を行っても，EP の振幅や潜時には影 響を与えない。したがって, 挫減直後の EP の変化は, 一定以上の挫隇を受けた線維の総数と比例関係を有する はずである.

これに対して，回復過程に打けるEPの变化の原因は もっと複雑であると考えられる。 その原因は末梢性要因 と中权性要因とに分けられる。末梢性要因では, 各神経 線維に対する挫減の程度が重要な関係を有する，挫隇の 程度は神経再生速度と相関を有するはずである。したが って, EP の回復に対する影響は, 挫減された線維の数 とそのおのおのの線維の挫减程度の関数となる.さら に, 挫隇から回復して来つつある神経線維の直径, すな わち伝導速度の問題も関係してくる。伝導速度の小さな ものが先に回復すれば，EP の潜時の回復は遅れる。伝 導速度がさまざまに異なった線維群の回復が先行すれ は， 大脳皮質に到着するインパルスの同期性が低いた め, EP の振幅は小さく，振幅の回復は外見上遅延する ことになる，中权性要因には，脳幹の中継核での変化と 大脳皮質バレル領野での変化とがある，本実験の方法で
は脳幹の変化については知ることができない，しかし， 挫減後の末梢々中枢の対応関係は，挫減された末梢神経 の神経外鞘が保存されていれば，注ぼ元通りに再建され るとされる12)ので，脳幹での変化はそれほど重大ではな いと思われる。本実験においても，バレル領野の EP で みられた潜時と振幅の変化はほとんぞの例で 3 週前後で 回復しているので, EP の変化の主要な原因は末梢性要 因に基づくものと推測される。 この推論を支持するもの として Renehan と Munger ${ }^{28)}$ の研究結果がある. 彼ら はラットの眼窩下神経を挫減した後の洞毛の神経再支配 を钼察し，挫減後第 2 週から再支配が始をると記載して いる. 本実験では，洞毛の神経再支配開始時点とほぼ同 時（第 2 週）に EP が回復する例があったが，これらの 例では中枢性要因の役割は小さいと考えられる。

\section{EP の変化に関与する中枢性機序}

（1）潜時の変化

挫减側 (左側) 刺激により対側（右側）頭部に誘発さ れた EP の陽および陰性波の潜時は，すべての例で延長 した，この原因の一つは，挫隇により上行性インパルス を送るチャンネル数が減少した結果, シナプスでの興畕 性変化の加重が減少し, 活動電位の発生が遅延したため であろう。もら一つの可能性としては, 挫減操作により 比較的太い線維が多数障害された結果, 洞毛刺激の情報 の伝達が同期性の比較的低い，すなわち伝導速度の遅い チャンネルに任されるようになったためであるら。また 陰性潜時の延長は, 主として陽性潜時の延長による 2 次 的なものであろう。しかし，上記の論理は挫減と同側 (左側) の頭部 EP の潜時については余り良く当てはま らない，潜時の延長があってもきわめてわずかで, 逆 に, 短縮する場合もある。 また，陰性潜時の変化の方向 が陽性潜時の方向と逆の場合もあり，陽性潜時の変化に よる 2 次的なものばかりとは考光にくい，特に，挫堿側 と同側のバレル領野へ向から経路の潜時がわずかである が短縮し，正常時の主要上行路である交叉性に対側に向 から経路の潜時よりもかえって短くなった場合があった ことは, 挫減側と同側のバレル領野の EP が対側バレル 領野を経由して, 左右大脳半球を結ぶ脳梁の交連線維を 介するものばかりではないことを示すとともに，中权神 経の可塑性 (plasticity) を示すものとしてきわめて興味 深い.ラットにとっては洞毛は環境の探索手段として, 嗅覚とともに最も重要であるので, 情報解析装置である バレル領野への上行路には安全装置としての代償機能が 備えられているのかもしれない. しかし，この非交叉性 の同側経路の短縮は末梢洞毛の神経再支配が開始される と考えられる挫減後第 2 週目には汪とんど認められなく なるので, 中权性代償機能の作動の慣性はきわ力て小さ く, 末梢の状態の変化に応じて急速な対応が可能である ことを示唆している. 
(2) 振幅の変化

挫隇側刺激によって, 交叉性に対側（右側）のバレル 領野へ上行する信号によって誘発された EP の振幅は小 さくなり，回復までは約 3 週間を要した。振幅の減少 は，第 1 週目では，陽性波よりも陰性波でより強く認め られた。陽性波が皮質下部から皮質への入力の総量と同 期性，そして皮質深部の興奮性を代表しているのに対 し，陰性波は皮質表層での興奮の強さを主に反映してい ることを考虑すれば，N/P 比の減少はバレル領野内部 での信号授受の阻害を示していることになる。この変化 も, 潜時变化と同様に, 末梢の修復が開始する第 2 週目 にほぼ回復した。

挫减側と同側 (左側) の EP の振幅は, 対側の EP と 同様に， 3 週前後で挫隇前の大きさに戻った。第 1 週目 には，陽性波の減少に比べて陰性波の減少が弱いか， たは振幅增強が見られたものがあった結果， N/P 比の 平均值が挫减前よりも大きくなった。 これは，挫隇と同 側のバレル領野内での信号伝達の促進や同期性興奮の増 強を示すものであろ5，この変化は，同し時期に挫減の 反対側のバレル領野でみられた EP 振幅の N/P 比の減 少と鏡像を成し，主として皮質内の代償機転によるもの であ万う。挫隇と同側の EP の陽性波の振幅の回復経過 の長さが挫隇直後の陽性波の減弱度と比較的良い対応関 係を示したことは, 同側性 EP の潜時の短縮や振幅の N/P 比の増大と考え合わせると，非交叉性の同側性経 路には感覚信号入力の減少に対応寸る代償性機転が働き らることを示唆するものと考えられる。

Waite $5^{16)}$ は, 新生ラットの眼简下神経を挫隇し対側 陽性潜時および振幅の推移を報告しているが，66日目で も挫隇群では対側陽性潜時が対照群と有意差を持って延 長し, 振幅も約 $1 / 3$ であるとしている. 今回の結果はそ れに比べ比較的早期の回復を見ているが，この差異の理 由は新生ラットにおける眼窩下神経の挫減は末梢一中 枢の対応関係に恒久的な变化を与えるため ${ }^{29)}$ と考えら れる。

以上まとめると，振幅においては，挫隇側刺激による 同側頭部 EP の陽性波の変化と回復経過との間に相関傾 向を認めたが, 今回の研究および他の研究者の結果でも 非常に偏差が大きく再生の指標としてはあまり信頼度が 高くなく，回復の目安としてはむしろ，図13，16亿示し たよ5に, 挫隇側刺激時の対側 N/P 比および同側 N/P 比の推移, 交叉性経路の $\mathrm{C} / \mathrm{I}$ 比の推移が指標としてよ り有用であると考えられる。

\section{結語}

ラットの洞毛刺激により惹起される頭皮下誘発電位 （EP）を利用して，眼窩下神経の挫隇後の回復過程を調 べた.
1. 採取された EPは, 刺激側洞毛から見て対側, 同 側ともに陽性成分と陰性成分から成る 2 相性波であっ た. 潜時は, 対側経路のほうが短かった。

2. 眼简下神経挫隇直後に, 挫隇側 (左) 洞毛刺激に上 り挫隇側と反対側（右）の EP の潜時が延長した。陽性 成分の延長度と陰性成分のそれとの間には比例関係が認 められた。挫隇側と同側の潜時は変化が少なかったが, かえって短縮する例では, 対側 EP の潜時よりも短くな る場合があった，挫隇直後の潜時延長が大きい場合で も，3週目までに大部分が回復した。

3. 眼窩下神経挫隇直後に, 挫隇側洞毛刺激による対 側 EP の振幅は，陽陰両成分とも低下した，同側の EP の陽性成分は全例低下を認めたが，陰性成分は低下する ものと增大するものとがほぼ同数であった. 回復時期と 同側の陽性成分の挫減直後の減弱度との間に, 正の相関 傾向を認めた。

4. 挫隇側刺激による潜時/健側刺激による潜時の比 （C/I 比）は陽・陰性両成分とも挫隇直後〜 1 週目まで 有意な増大を認めた。挫隇側洞毛刺激による片側頭部 EP の陰性成分の振幅/陽性成分の 振幅 (N/P 比) は, 対側頭部で挫隇直後〜 1 週目まで有意な減少を認めた. 挫隇側洞毛刺激による同側頭部 EP では, 逆に 1 週目に 有意な増大を認めた。これらの有意差は 2 週目にはすべ て消失した。

以上の結果から, 眼窩下神経挫减後の回復の指標とし ては, 挫减側刺激時の対側 N/P 比および同側 N/P 比 の推移, 交叉性経路の $\mathrm{C} / \mathrm{I}$ 比の推移を観察することが 有用と考えられる.

稿を終えるにあたり，終始こ悔篤なるこ指尊とこ校閲 を賜りました本教室主任河合幹教授に、謹んで感謝の 意を表します。また，本研究を遂行するにあたり，終始 こ懇篤なるこ教示こ指導を頂きました本学生理学教室佐 藤豊彦教授に深謝の意を表します。また，こ協力を頂き ました当教室, ならびに本学生理学教室の諸先生方に心 よりの感謝の意を表します。

本論文の要旨は, 第30回日本口腔外科学会総会 (1985 年, 東京）において発表した。

\section{引用文 献}

1) Franzén, O. and Offenloch, K.: Evoked resonse correlates of psychophysical magnitude estimates for stimulation in man. Exp Brain Res 8: 1-18 1969.

2) Johnson, D., Jürgens, R., et al.: Somatosensory evoked potentials and magnitude of perception. Exp Brain Res 22: 331-334 1975.

3) Yamauchi, N., Fujitani, Y., et al.: Somatosensory evoked potentials elicited by mechani- 
cal and electrical stimulation of each single pain or tactile spot of the skin. Tohoku J exp Med 133: 81-92 1981.

4) 村山伸樹：指電気刺激によるとト大脳誘発電位 と主観的感覚量との関連性. 日生理誌 47: 1711811985.

5) 斎藤次彦：神経切断䋖合後の sensory nerve action potential の実験的研究. 日大医誌 30：299 $-3111971$.

6) 町田和之：下菌槽神経切断後に扣ける変性と再 生に関与る央験的研究. 绦科学報 77：166116811977.

7) Bentley, F.H. and Schlapp, W.: The effects of pressure on conduction in peripheral nerve. J Physiol 102: 72-82 1943.

8）大湊八郎：家鬼末梢神経の再生に関する電気生 理学的ならびに組織学的研究。新潟医会誌 84 : 804-818 1970.

9）高田和雄：顔面神経修復手術の機能回復に関す 万実験的研究。日口外誌 29：2228-2240 1983.

10) Wexler, I.: Focal injury to nerve and associated altered sensory action potentials. Elctromyogr clin Neurophysiol 19: 371-379 1979.

11) Paul, R.L., Goodman, H., et al.: Alteration in mechanoreceptor input to Brodmann's areas 1 and 3 of the postcentral hand area of MACACA MULATTA after nerve section and regeneration. Brain Research 39: 1-19 1972.

12) Wall, J.T., Felleman, D.J., et al.: Recovery of normal topography in the somatosensory cortex of monkeys after nerve crush and regeneration. Science 221: 771-773 1983.

13) Woolsey, T.A. and Van der Loos, H.: The structural organization of Layer IV in the somatosensory region (SI) of mouse cerebral cortex. Brain Research 17: 205-242 1970.

14) Welker, C.: Microelectrode delineration of fine grain somatotopic organization of SmI cerevral neocortex in albino rat. Brain $\mathrm{Re}$ search 26: 259-275 1971.

15) Simons, D.J.. Response properties of vibrissa units in rat SI somatosensory neocortex. J Neurophysiol 41: 798-820 1978.

16) Waite, P.M.E. and Cragg, B.G.: The peripheral and central change resulting from cutting or crushing the afferent nerve supply to the whisker. Proc R Soc Lond B 214: 1942111982.

17) Pidoux, B. and Verley, R.: Projection on the cortical somatic I barrel subfield from ipsi- lateral vibrissae in adult rodents. Electro Clin Neurophysiol 46: 715-726 1979.

18) Hall, R.D. and Lindholm, E.P.: Organization of motor and somatosensory neocortex in the albino rat. Brain Research 66: 23-38 1974.

19) Axelrad, H., Verley, R., et al.: Responses evoked in mouse and rat SI cortex by vibrissa stimulation. Neuroscience Let 3: 265-274 1976.

20) Ito, M.: Some quantitative aspect of vibrissadriven neuronal responses in rat neocortex. J Neurophysiol 46: 705-715 1981.

21) Zucker, E. and Welker, W.I.: Coding of somatic sensory input by vibrissae neurons in the rat's trigeminal ganglion. Brain Research 12: 138-156 1969.

22) Arvidsson, J.: Somatotopic organization of vibrissae afferents in the trigeminal sensory neuclei of the rat studied by taransganglionic transport of HRP. J Comp Neurl 211: 84921982.

23) Waite, P.M.E.. Somatotopic organization of vibrissal responses in the ventrobasal complex of the rat thalamus. J Physiol 228: 527-540 1973.

24) Fukusima, T. and Kerr, F.E.L.: Organization of trigeminothalamic tracts and other thalamic afferent systems of the brainstem in the rat: Presence of gelantinosa neurons with thalamic connections. J Comp Neurl 183: 169-184 1979.

25) Clark, D.A., Hughes, J., et al.: Afferent function in the group of nerve fiber of slowest conduction velocity. Am J Physiol 114: 69741935.

26）菅野卓郎：末梢神経王迫麻㾴の電気生理学的研 究. 日外宝函 34:724-738 1965.

27) Waite, P.M.E. and Cragg, B.G.: The effect of destroying the whisker follicles in mice on the sensory nerve, the thalamocortical radiation and cortical barrel development. Proc R Soc Lond B 204: 41-55 1979.

28) Renehan, W.E. and Munger, B.L.: Degeneration and regeneration of peripheral nerve in the rat trigeminal system. II . Response to nerve lesions. J Comp Neurl 249: 429-459 1986.

29) Van der Loos, H. and Woolsey, T.A.: Somatosensory cortex: structural alterations following early injury to sense organs. Science 179 : 395-398 1973. 